\title{
Personality Type, Adversity Quotient, and Challenges of Student-Athletes in a Catholic University
}

\author{
Brendly Ann C. Mateo ${ }^{1}$ and Chris Feli Joy P. Tajonera ${ }^{2}$ \\ 1,2University of Negros Occidental-Recoletos, Bacolod City, Philippines
}

\begin{tabular}{l} 
Article history \\
Submitted: 25 June 2020 \\
Revised: 30 October 2020 \\
Accepted: 12 November 2020 \\
\hline Keywords \\
Guidance and Counseling \\
Personality Type \\
Adversity Quotient \\
Challenges \\
Student-Athletes \\
Descriptive-Correlational \\
Bacolod City
\end{tabular}

Introduction. Student-athletes are a unique student population requiring support for academic, personal, and athletic needs and issues. As the student-athletes deal with wins and losses, their ability to cope with failures will greatly help. However, the means of how to address these difficulties differ in any way. Hence, this study aspires to explore the personality type, adversity quotient, and challenges studentathletes face in a Catholic university during the academic year 20192020. Likewise, it explores the differences between the respondents' demographics and their personality type and adversity quotient. Also, it determines whether a correlation exists between personality type and the adversity quotient of student-athletes. Moreover, it delves into the challenges encountered by student-athletes.

Methods. A descriptive, comparative-correlational research design was used to assess the personality type, adversity quotient, and challenges of student-athletes in a Catholic University during the Academic Year 2019-2020. Utilizing the purposive sampling technique, 76 studentathletes participated in the study. The data was gathered using two standardized questionnaires and a researcher-made checklist. Mean, Standard Deviation, Mann Whitney U-test, Kruskal-Wallis, and Eta correlation were used to analyze the data.

Results. Findings of the study revealed that the majority of the respondents have the choleric temperament. Also, results showed that the level of adversity quotient of student-athletes is generally low. Moreover, in comparing the respondents' level of adversity quotient by demographics, there is a significant difference when the participants are grouped according to sex and type of sports. Meanwhile, there was no significant difference in the level of adversity quotient of student-athletes when grouped according to years of playing. In addition, when the participants were grouped according to personality type, no significant difference was observed. Furthermore, the study revealed no relationship exists between the personality type and adversity quotient of student-athletes. In addition, student-athletes generally recognized the lack of meals and energy drinks during games, inadequate financial support, difficulty in completing classwork and training, maintaining good grades for eligibility, and missing classes due to team conflicts as the most challenging part of being student-athletes. Hence, the overall result of the study showed that personality type is not associated with adversity quotient.

Conclusion. The Catholic university studied has a good composition of student-athletes because most of them are goal-oriented, persuasive, competitive, confident, and strong-willed. These characteristics may contribute to the good sports record of the university; however, the negative aspect of a choleric person like quick to anger and neglectful must be taken into consideration. Due to low-average levels of adversity quotient, student-athletes in a catholic university have low motivation, energy, performance, and persistence. They are more susceptible to a crisis of hope, which will eventually lead to depression. It implies that the majority of student-athletes are prone to depression and other related mental health issues. Also, little relationship exists between personality type and adversity quotient is seen based on the result of the study. It implies that one or two of the temperament types may elicit a relationship but not all of them.

Practical Value of the Paper. The findings of the study provided baseline information to school administration, sports director, and guidance counselors in formulating a wellness program to help 
the student-athletes develop a higher level of adversity quotient to better address life's adversities.

\section{References}

Apaak, D \& Sarpong, E. (2015) Internal Challenges Affecting Academic Performance of Student-Athletes in Ghanaian Public Universities. Journal of Education and Practice ISSN 222-1735 (paper) ISSN 222-288X (Online) Vol. 6, No. 14, 2015. Retrieved January 2020 from www.iiste.org.

Bojanowska, A., \& Zalewska, A. M. (2017). Happy temperament? Four types of stimulation control are linked to four types of subjective well-being. Journal of Happiness Studies, 18(5), 1403-1423. doi: http://dx.doi.org/10.1007/ s10902-016-9777-2.

Cando, J., \& Villacasten, L. (2014). The Relationship Between Adversity Quotient (AQ) and Emotional Quotient (EQ) and Teaching Performance of College PE Faculty Members of CIT University. International Journal of Sciences. Basic and Applied Research (IJSBAR). 18. 345-367.

Embalzado, H., \& Varma, P. (2017). Influences of Temperament Types on University Students 'Wellbeing, Academic Performance, and College Adjustment. Thai-Journal Human Sciences Vol.9, No. 2

Lu, L. D., Heinze, K. L., \& Soderstrom, S. (2018). Playing Multiple Positions: Student-Athlete Identity Salience and Conflict. Journal of Intercollegiate Sport, 11(2), 214-241. https://doi.org/10.1123/jis.2018-0034

Santos, A. E. (2018). Perceptions of pre-service teachers basketball athletes on their

performance rating for profiling. Asia Pacific Higher Education Research Journal, Vol.5, No.1(2018). Retrieve February 2020 from http://po/pnuresearchportal.org/ejournal/ index.php/apherj/ article/view/868.

Sorkkila, M, Tolvanen, A, Aunola, K, Ryba, TV. The role of resilience in student-athletes' sport and school burnout and dropout: A longitudinal person-oriented study. Sc and J Med Sci Sports. 2019; 29: 1059- 1067. https:// doi.org/10.1111/sms.13422.

Surujlal, J., Van Zyl, Y., \& Nolan, V. T. (2013). Perceived Stress and Coping Skills of University Student-Athletes and the Relationship with Life Satisfaction. African Journal of Physical Health Education, Recreation and Dance, 19, 1047-1059.

Wu, H., Li, Y., Yan, B., Hao, Z. (2015). Dynamic and Quantitative CiteSpace Analysis of Chinese Sports Discipline in the Past Decade. Advances in Physical Education. 06. 135-143. 10.4236/ape.2016.62015.

Ziaee V., Lotfian S., Amini H., Mansournia MA., Memari AH. Anger in Adolescent Boy Athletes: a Comparison among Judo, Karate, Swimming, and Non-Athletes. Iran J Pediatr. 2012;22(1):9-14.

\section{Correspondence:}

Brendly Ann C. Mateo [mateobrendzlee@gmail.com]

https://orcid.org/0000-0003-0447-0707 